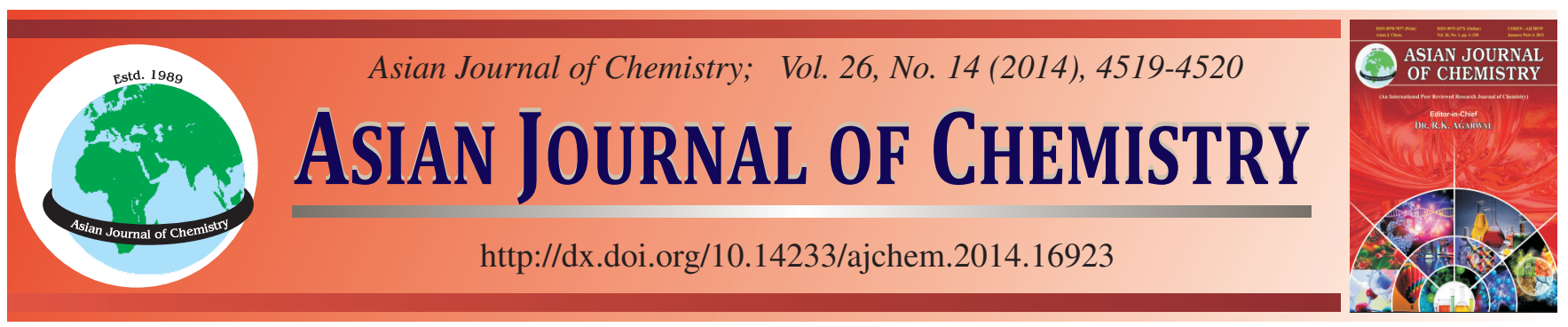

NOTE

\title{
A New Anthraquinone from the Fruit of Cassia fistula and Its Cytotoxicity
}

\author{
Juanxia Yang, Huan Wang, Guiyou Liu, Jie Lou, Limei Li, Qiufen Hu and YanQing Ye*
}

Key Laboratory of Chemistry in Ethnic Medicinal Resources, State Ethnic Affairs Commission and Ministry of Education, Yunnan University of Nationalities, Kunming 650031, P.R. China

*Corresponding author: E-mail: yey-qing@163.com

Received: 24 December 2013;

Accepted: 9 April 2014;

Published online: 5 July 2014;

AJC-15511

A new anthraquinone, fistulaquinone A (1) was isolated from the fruits of Cassia fistula. Its structure was elucidated by spectroscopic methods, including extensive 1D- and 2D NMR techniques. This new compound $\mathbf{1}$ was tested for its cytotoxicity and it showed potential cytotoxicity against NB4 and PC3 cell with $\mathrm{IC}_{50}$ values of 6.3 and $5.8 \mu \mathrm{M}$.

Keywords: Anthraquinone, Cassia fistula, Cytotoxicity.

Cassia fistula L., (Leguminosae) is an ornamental tree with beautiful yellow flowers ${ }^{1}$. In China, it has been used as traditional Chinese medicine by people of Dai nationality, who lived in Xishuangbanna, Yunnan province for treatment of diarrhea, gastritis, ringworm and fungal skin infections ${ }^{2,3}$. Previous phytochemical studies of $C$. fistula have shown the presence of anthraquinones ${ }^{4,5}$, steroids ${ }^{6}$, chromones $^{7,8}$, and flavonoids ${ }^{9}$. Motivated by a search for new bioactive metabolites from local plants, our group investigated the chemical constituents of the fruits of $C$. fistula growing in Xishuangbanna Prefecture, which led to the isolation and characterization of a new anthraquinone (1). This paper deals with the isolation, structural characterization and the cytotoxicity of this new compound.

UV spectra were obtained using a Shimadzu UV-2401A spectrophotometer. IR spectra were obtained in $\mathrm{KBr}$ disc on a Bio-Rad Wininfmred spectrophotometer. ESI-MS were measured on a VG Auto Spec-3000 MS spectrometer. ${ }^{1} \mathrm{H}-,{ }^{13} \mathrm{C}$ and $2 \mathrm{D}$ NMR spectra were recorded on Bruker DRX-500 instrument with TMS as internal standard. Column chromatography was performed on silica gel (200-300 mesh), or on silica gel H (10$40 \mu \mathrm{m}$, Qingdao Marine Chemical Inc., China). Second separation was performed by an Agilent $1100 \mathrm{HPLC}$ equipped with ZORBAX-C ${ }_{18}(21.2 \times 250,7.0 \mu \mathrm{m})$ column and DAD detector.

Fruits of Cassia fistula L., (Leguminosae) were collected in Xishuangbanna Prefecture, Yunnan Province, People's Republic of China, in September 2011. The identification of the plant material was verified by Prof. Yuan. N (Xishuangbanna Botanical Garden). A voucher specimen (YNNI-2010-9-28) has been deposited in our laboratory.
Extraction and isolation: Air-dried and powdered fruits of C. fistula $(2.2 \mathrm{~kg})$ were extracted four times with $70 \%$ acetone $(4 \times 5 \mathrm{~L})$ at room temperature and filtered. The crude extract (126 g) was applied to silica gel (200-300 mesh) column chromatography, eluting with a $\mathrm{MeOH}-\mathrm{CHCl}_{3}$ gradient system $(9: 1,8: 2,7: 3,6: 4,5: 5)$, to give five fractions A-E. The further separation of fraction A $(9: 1,22.6 \mathrm{~g})$ by silica gel column chromatography, eluted with $\left(\mathrm{CH}_{3}\right)_{2} \mathrm{CO}-\mathrm{CHCl}_{3}(9: 1,8: 2,7: 3$, $6: 4,1: 1)$, yielded the subfraction A1-A5. The subfraction A1 (9:1, $5.6 \mathrm{~g})$ was subjected to preparative HPLC $(65 \% \mathrm{MeOH}$, flow rate $12 \mathrm{~mL} / \mathrm{min})$ to give $\mathbf{1}(14 \mathrm{mg})$.

Fistulaquinone $A$ (1): $\mathrm{C}_{20} \mathrm{H}_{14} \mathrm{O}_{7}$, Obtained as yellow powder; UV (MeOH), $\lambda_{\max }(\log \varepsilon) 368$ (3.57), 282 (4.16), 258 (3.83), $210(4.36) \mathrm{nm}$; IR (KBr, $\left.v_{\max }, \mathrm{cm}^{-1}\right)$ 3395, 2926, 2873, 1690, 1652, 1608, 1560, 1487, 1423, 1368, 1273, 1161, 1131, 1068, 876, 763; ${ }^{1} \mathrm{H}$ and ${ }^{13} \mathrm{C} \mathrm{NMR}$ data $\left(\mathrm{CDCl}_{3}, 500\right.$ and $\left.125 \mathrm{MHz}\right)$, Table-1; ESI-MS (positive ion mode) $\mathrm{m} / z, 389[\mathrm{M}+\mathrm{H}]^{+}$; HRESI-MS (positive ion mode) $\mathrm{m} / z 389.0632[\mathrm{M}+\mathrm{H}]^{+}$(calcd 389.0637 for $\mathrm{C}_{20} \mathrm{H}_{14} \mathrm{NaO}_{7}$ ).

The air-dried and powdered fruits of C. fistula $(2.2 \mathrm{~kg})$ was extracted with $70 \%$ aqueous acetone $(4 \times 5 \mathrm{~L})$ at room temperature and filtered to yield a filtrate, which was successively evaporated under reduced pressure to obtain a crude extract (126 g). This crude extract was subjected repeatedly to column chromatography on Silica gel, Sephadex LH-20, RP18 and preparative HPLC to afford compound $\mathbf{1}$. Its structures were shown in Fig. 1 . The ${ }^{1} \mathrm{H}$ - and ${ }^{13} \mathrm{C}$ NMR data of the compound $\mathbf{1}$ was listed in Table-1. 
<smiles>COc1cc(O)c2c(c1)C(=O)c1cc(C)c3c(=O)cc(CO)oc3c1C2=O</smiles>

Fig. 1. Structure of compound $\mathbf{1}$

\begin{tabular}{ccc|ccc}
\multicolumn{6}{c}{ TABLE-1 } \\
${ }^{1} \mathrm{H}$ AND ${ }^{13} \mathrm{C}$ NMR DATA OF COMPOUND $1(\delta \mathrm{IN} \mathrm{ppm,} \mathrm{IN} \mathrm{CDCl})$ \\
\hline No. & $\delta_{\mathrm{C}}(\mathrm{m})$ & $\begin{array}{c}\delta_{\mathrm{H}}(\mathrm{m}, \\
J=\mathrm{Hz})\end{array}$ & No. & $\delta_{\mathrm{C}}(\mathrm{m})$ & $\begin{array}{c}\delta_{\mathrm{H}}(\mathrm{m}, \\
J=\mathrm{Hz})\end{array}$ \\
\hline 1 & $124.5 \mathrm{~d}$ & $7.58, \mathrm{~s}$ & $9 \mathrm{a}$ & $121.5 \mathrm{~s}$ & - \\
2 & $144.4 \mathrm{~s}$ & - & 10 & $182.3 \mathrm{~s}$ & - \\
3 & $133.3 \mathrm{~s}$ & - & $10 \mathrm{a}$ & $125.2 \mathrm{~s}$ & - \\
4 & $155.2 \mathrm{~s}$ & - & $1^{\prime}$ & $182.6 \mathrm{~s}$ & - \\
$4 \mathrm{a}$ & $117.6 \mathrm{~s}$ & - & 2 & $108.5 \mathrm{~d}$ & $6.50, \mathrm{~s}$ \\
5 & $184.5 \mathrm{~s}$ & - & 3 & $168.6 \mathrm{~s}$ & - \\
$5 \mathrm{a}$ & $113.3 \mathrm{~s}$ & - & 4 & $62.3 \mathrm{t}$ & $4.46, \mathrm{~s}$ \\
6 & $160.5 \mathrm{~s}$ & - & 5 & $18.6 \mathrm{q}$ & $2.08, \mathrm{~s}$ \\
7 & $107.2 \mathrm{~d}$ & $6.96, \mathrm{~s}$ & $-\mathrm{OMe}-8$ & $55.9 \mathrm{q}$ & $3.81, \mathrm{~s}$ \\
8 & $166.4 \mathrm{~s}$ & - & Ar-OH-6 & - & $12.28, \mathrm{~s}$ \\
9 & $109.2 \mathrm{~d}$ & $7.13 \mathrm{~s}$ & - & - & - \\
\hline
\end{tabular}

Compound 1 was isolated as a yellow powder: Highresolution ESIMS analysis gave a quasi-molecular ion at $\mathrm{m} / \mathrm{z}$ $389.0632[\mathrm{M}+\mathrm{H}]^{+}$, consistent with a molecular formula of $\mathrm{C}_{20} \mathrm{H}_{14} \mathrm{O}_{7}$, which indicated 14 degrees of unsaturation. The UV spectrum of 1 exhibited absorption bands at 368, 282, 258 and $210 \mathrm{~nm}$, highly suggesting the existence of aromatic chromophore $^{10}$. Strong absorption bands accounting for hydroxy $\left(3395 \mathrm{~cm}^{-1}\right)$, carbonyl $\left(1690,1652 \mathrm{~cm}^{-1}\right)$ and aromatic groups $\left(1608,1560\right.$ and $\left.1487 \mathrm{~cm}^{-1}\right)$ could also be observed in its IR spectrum. The ${ }^{1} \mathrm{H}$ NMR spectrum of $\mathbf{1}$ (Table-1) showed the presence of one phenolic hydroxy proton $\left(\delta_{\mathrm{H}} 12.28\right)$, one methoxy proton $\left(\delta_{\mathrm{H}} 3.81\right)$, four singlet aromatic protons $\left(\delta_{\mathrm{H}}\right.$ $7.58,6.96,7.13$ and 6.50$)$ and two aliphatic protons contributed by one methyl singlet $\left(\delta_{\mathrm{H}} 2.08\right)$, one O-methylene singlet $\left(\delta_{\mathrm{H}}\right.$ 4.46). In the ${ }^{13} \mathrm{C}$ NMR spectrum of 1 (Table-1), $14 s p^{2}$ carbon signals, including three oxygenated quaternary $s p^{2}$ carbon signals $\left(\delta_{\mathrm{C}} 155.2,160.5\right.$ and 166.4$)$ and two carbonyl carbon signals $\left(\delta_{\mathrm{C}} 184.5\right.$ and 182.3$)$ were observed, which highly suggested the presence of anthraquinone core ${ }^{10}$.

The additional carbons account for the remaining substituents, a methoxy group $\left(\delta_{\mathrm{C}} 55.9 \mathrm{~s}\right)$, a hydroxymethyl chromone ring $\left(\delta_{\mathrm{C}} 182.6 \mathrm{~s}, 108.5 \mathrm{~d}, 168.6 \mathrm{~s}, 62.3 \mathrm{t}\right)^{11}$, and a methyl carbon $\left(\delta_{\mathrm{C}} 18.6\right)$ on the anthraquinone ring. The substituents and their location on the anthraquinone ring were established by analysis of the HMBC spectra of 1 (Fig. 2). The HMBC correlations from a methyl singlet $\left(\delta_{\mathrm{H}} 2.08\right)$ to $\mathrm{C}-1\left(\delta_{\mathrm{C}} 124.5\right), \mathrm{C}-2\left(\delta_{\mathrm{C}}\right.$ $144.4)$ and $C-3\left(\delta_{C} 133.3\right)$ established the location of a methyl group at $\mathrm{C}-2$. HMBC correlations between the hydroxy proton
$\left(\delta_{\mathrm{H}} 12.28\right)$ and C-6 $\left(\delta_{\mathrm{C}} 160.5\right), \mathrm{C}-7\left(\delta_{\mathrm{C}} 107.2\right)$ and C-5a $\left(\delta_{\mathrm{C}}\right.$ 113.3), led to the assignment of the phenolic hydroxy group at $\mathrm{C}-6$. The methoxy group located at C-8 was supported by the HMBC correlation of the methoxy proton $\left(\delta_{\mathrm{H}} 3.81\right)$ with C-8 $\left(\delta_{\mathrm{C}} 166.4\right)$. Additionally, $\mathrm{H}-2^{\prime}\left(\delta_{\mathrm{H}} 6.50\right)$ showed correlation with the carbon signal of C-3 $\left(\delta_{\mathrm{C}} 133.3\right)$ clearly indicated that the hydroxymethyl chromone ring should be located between C-3 and C-4. On the basis of the above evidence, the structure of $\mathbf{1}$ was established as shown and given the trivail name of fistulaquinone A.

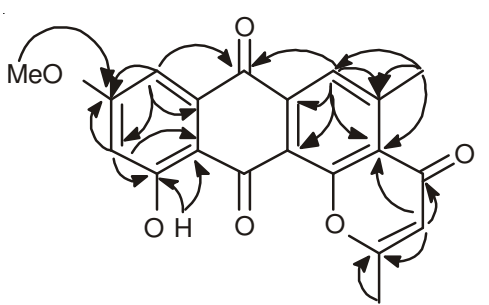

Fig. 2. Key HMBC (a) correlation of $\mathbf{1}$

Compound $\mathbf{1}$ were tested for its cytotoxicity against five tumor cells line (NB4, A549, SHSY5Y, PC3 and MCF7) using a previously reported procedure ${ }^{12}$. The results showed that $\mathbf{1}$ exhibited potential cytotoxicity against $\mathrm{NB}_{4}$ and $\mathrm{PC}_{3}$ cell with $\mathrm{IC}_{50}$ values of 6.3 and $5.8 \mu \mathrm{M}$.

\section{ACKNOWLEDGEMENTS}

This research was supported by the National Natural Science Foundation of China (No. 21302164) and the excellent Scientific and Technological Team of Yunnan High School (2010CI08).

\section{REFERENCES}

1. V. Duraipandiyan and S. Ignacimuthu, J. Ethnopharmacol., 112, 590 (2007).

2. S. Rajan, D.S. Baburaj, M. Sethuraman and S. Parimala, Ethnobotany, 6, 19 (2001).

3. J. Ma, L.X. Zhang and Y.H. Guan, Chin. J. Ethnomed. Ethnopharm., 5, 178 (2004).

4. K.A. Abo, A.A. Adeyemi and A.O. Sobowale, Afr. J. Med. Med. Sci., 30, 9 (2001).

5. S. Aurapa and G. Wandee, Int. J. Biomed. Pharm. Sci., 3, 42 (2009).

6. P. Sartorelli, S.P. Andrade, M.S. Melhem, F.O. Prado and A.G. Tempone, Phytother. Res., 21, 644 (2007).

7. Y.H. Kuo, P.H. Lee and Y.S. Wein, J. Nat. Prod., 65, 1165 (2002).

8. S.L. Jothy, Z. Zakaria, Y. Chen, Y.L. Lau, L.Y. Latha, L.N. Shin and S. Sasidharan, Molecules, 16, 7583 (2011).

9. W. Zhao, X.Y. Zeng, T. Zhang, L. Wang, G.Y. Yang, Y.K. Chen, Q.F. Hu and M.M. Miao, Phytochem. Lett., 6, 179 (2013).

10. Y.C. Hu, E.D. Martinez and J.B. MacMillan, J. Nat. Prod., 75, 1759 (2012).

11. P. Tuntiwachwuttikul, P. Phansa, Y. Pootaeng-On and W.C. Taylor, Chem. Pharm. Bull. (Tokyo), 54, 44 (2006).

12. X.M. Gao, R.R. Wang, D.Y. Niu, C.Y. Meng, L.M. Yang, Y.T. Zheng, G.Y. Yang, Q.F. Hu, H.D. Sun and W.L. Xiao, J. Nat. Prod., 76, 1052 (2013). 